\title{
Interactive effects of land use history and natural disturbance on seedling dynamics in a subtropical forest
}

\author{
Liza S. Comita, ${ }^{1,6}$ Jill Thompson, ${ }^{2,7}$ Maria Uriarte, ${ }^{1}$ Inge Jonckheere, ${ }^{3,4}$ Charles D. Canham, ${ }^{5}$ \\ AND JESS K. ZIMMERMAN ${ }^{2}$ \\ ${ }^{1}$ Department of Ecology, Evolution and Environmental Biology, Columbia University, 1200 Amsterdam Avenue, \\ New York, New York 10027 USA \\ ${ }^{2}$ Institute for Tropical Ecosystem Studies, University of Puerto Rico, P.O. Box 21910, San Juan, Puerto Rico 00931-3341 USA \\ ${ }^{3}$ Biosystems Department, Geomatics Group, Katholieke Universiteit Leuven, 3001 Heverlee, Belgium \\ ${ }^{4}$ Forest Management Division, Forestry Department, FAO HQ, 00153, Rome, Italy \\ ${ }^{5}$ Cary Institute of Ecosystem Studies, Box AB, Millbrook, New York 12545 USA
}

\begin{abstract}
Human-impacted forests are increasing in extent due to widespread regrowth of secondary forests on abandoned lands. The degree and speed of recovery from human disturbance in these forests will determine their value in terms of biodiversity conservation and ecosystem function. In areas subject to periodic, severe natural disturbances, such as hurricanes, it has been hypothesized that human and natural disturbance may interact to either erase or preserve land use legacies. To increase understanding of how interactions between human and natural disturbance influence forest regeneration and recovery, we monitored seedlings in a human- and hurricane-impacted forest in northeastern Puerto Rico over a $\sim 10-\mathrm{yr}$ period and compared seedling composition and dynamics in areas that had experienced high- and low-intensity human disturbance during the first half of the 20th century. We found that land use history significantly affected the composition and diversity of the seedling layer and altered patterns of canopy openness and seedling dynamics following hurricane disturbance. The area that had been subject to high-intensity land use supported a higher density, but lower diversity, of species. In both land use history categories, the seedling layer was dominated by the same two species, Prestoea acuminata var. montana and Guarea guidonia. However, seedlings of secondary-successional species tended to be more abundant in the high-intensity land use area, while late-successional species were more abundant in the low-intensity area, consistent with patterns of adult tree distributions. Seedlings of secondaryforest species showed greater increases in growth and survival following hurricane disturbance compared to late-successional species, providing support for the hypothesis that hurricanes help preserve the signature of land use history. However, the increased performance of secondary-forest species occurred predominantly in the low-intensity land use area, suggesting that hurricanes act to homogenize differences in species composition between areas with differing land use histories by increasing secondary-forest species regeneration in areas that experienced little direct human disturbance. Our results suggest that, through effects on seedling dynamics, hurricanes may extend the signature of land use history beyond the average recovery time of forests not subject to intense natural disturbance events.
\end{abstract}

Key words: disturbance; forest dynamics; Guarea guidonia; land use history; long-term ecological research; Luquillo Forest Dynamics Plot, Puerto Rico; Prestoea acuminata var. montana; recruitment limitation; regeneration niche; secondary forest; succession; tropical forest.

\section{INTRODUCTION}

It is now widely accepted that the majority of forests worldwide have been impacted to some degree by human activity (Gómez-Pompa and Kaus 1992, Clark 1996, Chazdon 2003). In fact, secondary and degraded forests

Manuscript received 24 July 2009; revised 6 October 2009; accepted 12 October 2009. Corresponding Editor: E. Cuevas.

${ }^{6}$ Present address: National Center for Ecological Analysis and Synthesis, 735 State Street, Suite 300, Santa Barbara, California 93101 USA. E-mail: lcomita@gmail.com

${ }^{7}$ Present address: Centre for Ecology and Hydrology (Edinburgh), Bush Estate, Penicuik, Midlothian EH260QB United Kingdom. now cover a larger area than remaining old growth forests (ITTO 2002). In the tropics, the extent of secondary forests is expected to increase as forests continue to regenerate following human land use and subsequent abandonment (Wright 2005). In these secondary forests, land use history can have a significant, long-term signature on species composition (García-Montiel and Scatena 1994, Finegan 1996, Gauriguata and Ostertag 2001, Rhemtulla et al. 2009), diversity (Rivera et al. 2000, Dambrine et al. 2007), and ecosystem function (Silver et al. 2000, 2004, Chazdon 2008, Kauffman et al. 2009), often exceeding the influence of geography or environmental factors (Foster et al. 1998a, Burslem et al. 2000, 
Boucher et al. 2001, Thompson et al. 2002). Recent debate on the conservation value of secondary forests in the tropics remains unresolved due, in part, to a lack of data on the ability of these forests to fully recover from past human disturbance (Gardner et al. 2007).

In addition to human impacts, forest communities are shaped by a variety of natural disturbances (Sousa 1984, Pickett and White 1985). Much attention has been given to small-scale disturbance associated with tree fall gaps (e.g., special feature in Ecology 70(3), 1989); however, many forests also experience periodic, severe disturbances, such as wind storms, fires, and droughts (Everham and Brokaw 1996, Whitmore and Burslem 1998). These large-scale natural disturbances may interact with human disturbance in a number of ways that could result in short-term, long-term, or permanent shifts in forest composition and ecosystem function (Chazdon 2003, Uriarte et al. 2004b, 2009, Catterall et al. 2008). For example, increasing dominance of fastgrowing pioneer and secondary-forest species, which typically have lower wood densities (Swaine and Whitmore 1988, Muller-Landau 2004, King et al. 2005), could alter the long-term carbon storage capacity of forests (Korner 2004). Understanding shifts in species composition that result from interactions between human and natural disturbance is, therefore, critical for predicting the future structure and long-term conservation value of these forests (Paine et al. 1998) and evaluating their role in climate change mitigation.

In temperate and tropical forests of many coastal regions, cyclonic storms, referred to as hurricanes, typhoons, or cyclones, are a major cause of natural disturbance (Boose et al. 1994, Everham and Brokaw 1996, Lugo 2008). These storms typically result in defoliation, branch and stem breakage, uprooting, and tree mortality (Brokaw and Walker 1991, Zimmerman et al. 1994, Everham and Brokaw 1996). Previous studies have shown that human land use history affects the extent and spatial distribution of damage during these storms because secondary-forest species are more likely to be damaged by hurricane-force winds (Zimmerman et al. 1994, Burslem and Whitmore 1999, Franklin et al. 2004). Therefore, it has been hypothesized that cyclonic storms may act to erase the signature of past land use by hastening the decline of secondary-forest species and causing a shift toward late-successional species that are less susceptible to damage during intense storm events (Zimmerman et al. 1994, Ogle et al. 2006).

Changes in forest composition as a result of hurricane disturbance are not only caused by adult tree damage and mortality, but may also be influenced by patterns of recruitment following storms. In human-impacted forests, the greater damage to adult trees of secondary-forest species could lead to conditions in the understory that favor the recruitment and survival of their seedlings. Specifically, greater damage to the canopy increases understory light levels, which, in turn, may favor seedlings of light-demanding species characteristic of secondary forests. Thus, rather than hasten the decline of secondaryforest species, major storms could help such species persist through higher recruitment (Uriarte et al. 2009).

Despite the influence of seedling dynamics on future forest composition, community-level studies of seedlings in secondary tropical forests are rare (Capers et al. 2005). Furthermore, existing studies have predominantly been carried out in areas that do not experience severe natural disturbances (e.g., Guariguata et al. 1997, Capers et al. 2005, Norden et al. 2009). Thus, there is a lack of information on how land use history may alter the speed and trajectory of forest recovery via effects on seedling dynamics following large-scale natural disturbances.

To increase understanding of how interactions between human and natural disturbance influence forest regeneration and recovery, we established a communitywide study of seedlings in a hurricane-impacted forest in Puerto Rico that was subjected to a variety of human impacts in the first half of the 20th century. Here we describe changes in the seedling layer over a $\sim 10$-yr period following hurricane disturbance and compare woody seedling diversity and dynamics in areas with differing land use histories. Using these data, we test the hypothesis that hurricanes act to preserve land use legacies by promoting the successful regeneration of secondary-forest species. We predicted that, due to interactions between natural and human disturbance, hurricane-driven increases in seedling growth and survival would favor the regeneration of secondaryforest species in areas that had been subjected to a high intensity of past human land use.

\section{Methods \\ Study site}

The study was conducted in the 16-ha Luquillo Forest Dynamics Plot (LFDP) in northeastern Puerto Rico $\left(18^{\circ} 20^{\prime} \mathrm{N}, 65^{\circ} 49^{\prime} \mathrm{W}\right.$; see Plate 1). Rainfall at the site averages $3500 \mathrm{~mm}$ per year. A drier period occurs from January through April, but all months receive $>200 \mathrm{~mm}$ of rain (Thompson et al. 2004). Elevation in the LFDP ranges from 333 to $428 \mathrm{~m}$ above sea level (Fig. 1). All free-standing woody stems $\geq 1 \mathrm{~cm}$ dbh (diameter at 1.3 $m$ above ground) in the LFDP have been tagged, mapped, and identified to species at roughly 5-year intervals since 1990 (Thompson et al. 2002, 2004). The forest of the LFDP contains $\sim 13000$ stems $\geq 10 \mathrm{~cm} \mathrm{dbh}$ of 89 tree species (Thompson et al. 2002) and is classified as subtropical wet in the Holdridge life zone system (Ewel and Whitmore 1973) and tropical montane in Walsh's (1996) tropical climate system. The forest type is referred to locally as "tabonuco forest," after one of the dominant tree species, Dacryodes excelsa Vahl (Thompson et al. 2002).

\section{Disturbance history}

Natural disturbance.-The Luquillo forest was struck by Hurricane Hugo, a category 4 hurricane, in September 1989 (Scatena and Larsen 1991) and nine 


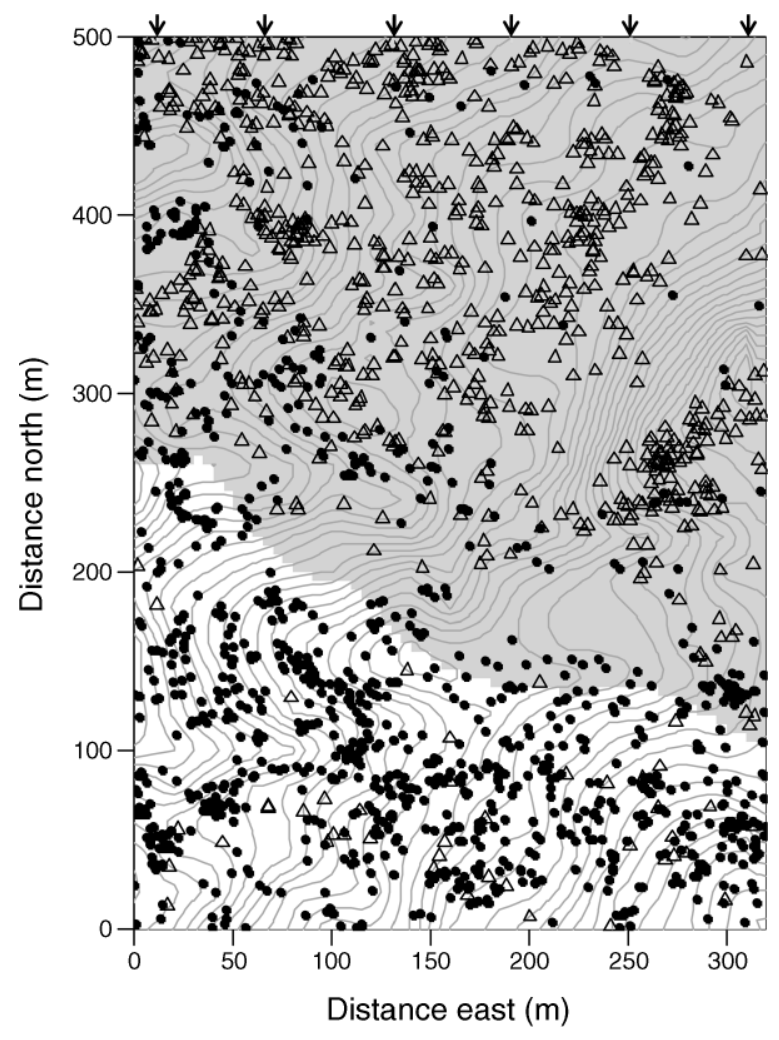

FIG. 1. Topographic map of the 16-ha Luquillo Forest Dynamics Plot, Puerto Rico, with 5-m contour intervals. The northern portion of the plot (gray) was subjected to highintensity historical human land use and, as a result, is dominated by trees of secondary-forest species, such as Casearia arborea (open triangles; trees $\geq 10 \mathrm{~cm}$ diameter at breast height [dbh] in 2000). The southern portion (white) was subjected only to low-intensity land use and contains higher abundances of late-successional species, such as Dacryodes excelsa (solid circles; trees $\geq 10 \mathrm{~cm}$ dbh in 2000). Arrows at the top mark the location of the six north-south running transects along which seedling plots were established at 20 -m intervals. The southwestern corner of the plot was at $18^{\circ} 20^{\prime} \mathrm{N}, 65^{\circ} 49^{\prime} \mathrm{W}$.

years later, on 21 September 1998, by Hurricane Georges, a category 3 storm with sustained winds of $184 \mathrm{~km} / \mathrm{h}$ and gusts up to $241 \mathrm{~km} / \mathrm{h}$ (Ostertag et al. 2003). Both hurricanes caused significant damage to the forest canopy in the Luquillo forest, including defoliation, branch breakage, stem snaps, tip-ups, and tree mortality (Walker 1991, Zimmerman et al. 1994, Ostertag et al. 2005, Ogle et al. 2006, Canham et al. 2009).

Human disturbance.-Portions of the LFDP were disturbed by humans prior to 1934, when the USDA Forest Service bought the land, effectively ending agriculture and logging in the area. Detailed land use history of the LFDP, based on aerial photos, historical records, and tree community at the time of Hurricane Hugo, can be found in Thompson et al. (2002). Using that information, we divided the LFDP into two different land use history categories for the purposes of this study (Fig. 1). We classified the northern twothirds of the LFDP as having a high intensity of past human disturbance. This area had $\leq 80 \%$ canopy cover in aerial photographs taken in 1936 (cover classes 1-3 in Thompson et al. 2002), as a result of heavy logging early in the 20th century, followed by about a decade of smallscale farming of a variety of crops (e.g., shade coffee, fruit trees) intermingled with remnants of the forest. The southern third of the plot was classified as having a low intensity of human disturbance (Fig. 1). This portion of the LFDP had $>80 \%$ canopy cover in aerial photographs taken in 1936 (cover class 4 in Thompson et al. 2002). The area had been subject to limited selective logging and timber stand improvement prior to 1953, but had not been clear-cut or used for agriculture (Thompson et al. 2002). Stem density and basal area are similar in the two land use history categories; however, land use history has a clear influence on present-day tree species composition, more so than differences in topography or soil type (García-Montiel 2002, Thompson et al. 2002; Fig. 1). A palm, Prestoea acuminata (Willd.) H.E. Moore var. montana (Graham) A. Hend. \& G. Galeano, is the dominant species among individuals $\geq 10 \mathrm{~cm}$ dbh in both portions of the plot, but has a higher relative abundance in the high-intensity land use history area. Abundant trees in the low-intensity land use area include late-successional species Dacryodes excelsa (Fig. 1), Manilkara bidentata (A. DC.) A. Chev, and Sloanea berteriana Choisy ex DC. In contrast, common trees in the high-intensity land use area include the secondary-forest species Casearia arborea (Rich.) Urb. (Fig. 1) and the pioneer species Cecropia schreberiana Miq. These differences in tree species composition drive the spatial distribution of hurricane damage because the species that colonized the more human-disturbed area tend to be more vulnerable to hurricane damage than late-successional species (Zimmerman et al. 1994, Thompson et al. 2002).

\section{Seedling censuses}

Following Hurricane Georges in September 1998, 150 seedling plots $(1 \times 2 \mathrm{~m})$ were established at $\sim 20$-m intervals along six north-south running transects spaced $60 \mathrm{~m}$ apart (Uriarte et al. 2005, Comita et al. 2009; Fig. 1). Forty-nine of these plots were located in the area of the LFDP with low human disturbance, and the remaining 101 plots were in the high human disturbance area. From March-April 2000 all free-standing, woody seedlings $\geq 10 \mathrm{~cm}$ tall and $<1 \mathrm{~cm}$ diameter at breast height (dbh) within the seedling plots were tagged, measured for height and root collar diameter, and identified to species. The seedling plots were recensused in April-June 2002, August-October 2004, FebruaryMarch 2007, and January-February 2008. Over the course of the study, a total of 13956 seedlings of 79 tree and shrub species were tagged.

To assess changes in understory light conditions over time after Hurricane Georges, hemispherical photographs were taken at a height of $1 \mathrm{~m}$ over the center of each seedling plot in March-April 1999 and again 
during seedling censuses in 2002, 2004, and 2007. We analyzed the photos using an automatic thresholding program that classifies color digital photographs into binary images, with pixels in black representing vegetation and pixels in white representing sky. The program first uses an automatic global thresholding algorithm combined with a local thresholding algorithm in order to correct for local light anomalies (e.g., sun flecks, underexposure) in the photographs (Jonckheere et al. 2005, 2006). Following this step, the percent canopy openness was calculated based on the fraction of pixels classified as sky, after weighting zenith rings by the portion of the hemisphere they represent.

\section{Analyses}

To investigate the effect of land use history and changing light conditions in the understory on seedling dynamics following hurricane disturbance, we compared seedling density at each census, and seedling recruitment, mortality and growth rates across census intervals, in the two land use history categories. Values were calculated for each seedling plot and then differences in values among years and between land use categories were analyzed using ANOVAs, after appropriate transformations were performed to meet standard statistical assumptions. Differences between land use history categories in each census were tested for using Wilcoxon rank sum tests, with $P$ values adjusted for multiple comparisons using the false discovery rate (FDR) method of Benjamini and Hochberg (1995).

Because of differences in area sampled and seedling density, we used rarefaction to compare diversity between land use categories and among censuses. We used plot-based rarefaction to assess diversity on a per unit area basis by randomly drawing 10 seedling plots 1000 times and calculating the mean number of species per draw. Similarly, we calculated diversity on a per individual basis by randomly drawing 100 individuals 1000 times and calculating the mean number of species per draw. Ninety-five percentage confidence intervals around diversity estimates were based on the 25th and 975th ranked values from the 1000 draws. Differences in the species composition of the seedling layer over time and between land use history categories were compared using Morisita's index of dissimilarity, which is not sensitive to sample size or diversity (Wolda 1981).

To test the hypothesis that seedlings of secondaryforest species are favored following hurricane disturbance, we examined changes in the seedling densities and relative abundances of 12 common tree species of known successional status (Thompson et al. 2002, Uriarte et al. 2009). Five of these species are considered latesuccessional species: Dacryodes excelsa, Manilkara bidentata, Sloanea berteriana, Tetragastris balsamifera (Sw.) Oken, and Guarea guidonia (L.) Sleumer. Another five are classified as secondary-forest species: Casearia arborea, Prestoea acuminata var. montana, Inga laurina (Sw.) Willd., Tabebuia heterophylla (DC.) Britton, and

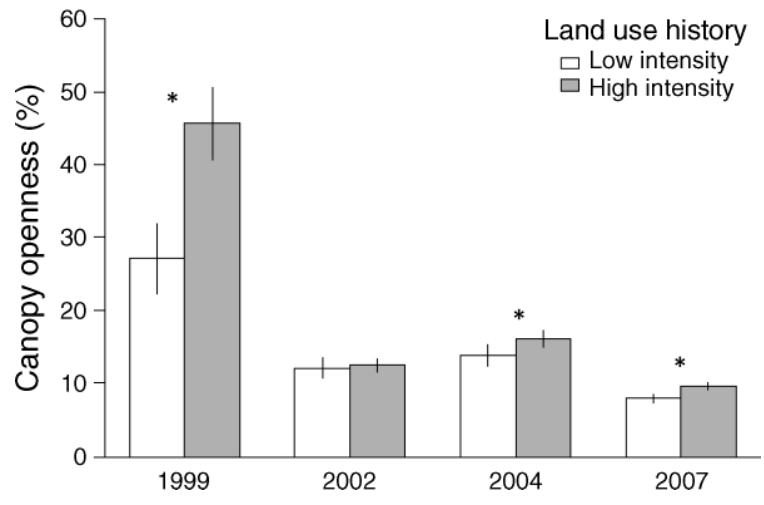

FIG. 2. Canopy openness as measured by percentage of light transmitted (mean $\pm 2 \mathrm{SE}$ ) in each census in the portions of the Luquillo Forest Dynamics Plot that had experienced high- vs. low-intensity human land use in the past. Asterisks denote years in which values differed significantly between land use history categories (adjusted $P<0.05$ ). For a description of the measurement of percent canopy openness see Methods: Seedling censuses.

Alchornea latifolia Sw. The remaining two species, Cecropia schreberiana and Schefflera morototoni (Aubl.) Maguire, Steyerm. \& Frodin, are considered pioneer species. Together, these 12 species make up $86 \%$ of the trees $\geq 10 \mathrm{~cm}$ dbh in the 2005 LFDP census and $80 \%$ of all seedlings encountered in the seedling plots during the study.

To test whether seedling survival and growth rates of late-successional and secondary-forest species were differently influenced by land use history and hurricane disturbance, we analyzed individual seedling survival and relative height growth rate (RGR) across each census interval as a function of: successional status (latesuccessional vs. secondary-forest species), land use history (low vs. high-intensity), and hurricane disturbance (damaged vs. recovered forest canopy), in addition to interactions among these three factors. Pioneer species were not included because of their small sample sizes. The results from the analysis of hemispherical canopy photos (Fig. 2) showed a distinct difference in canopy openness corresponding to high and low mean understory light levels between the initial and the later census times; therefore, we classified observations from the first census interval after Hurricane Georges as occurring under hurricane-damaged canopy and observations from later censuses as occurring under recovered canopy. Seedling survival was analyzed using a generalized linear mixed model with binomial errors, fit by the Laplace approximation (Bolker et al. 2009). Relative growth rate was analyzed using a linear mixed effects model with the REML estimation method (Venables and Ripley 2002). For both survival and RGR models, we included plot and species as random effects. For the survival model, seedling height was included as a covariate because smaller individuals are more likely to die first, potentially biasing survival estimates over time (Zens and 

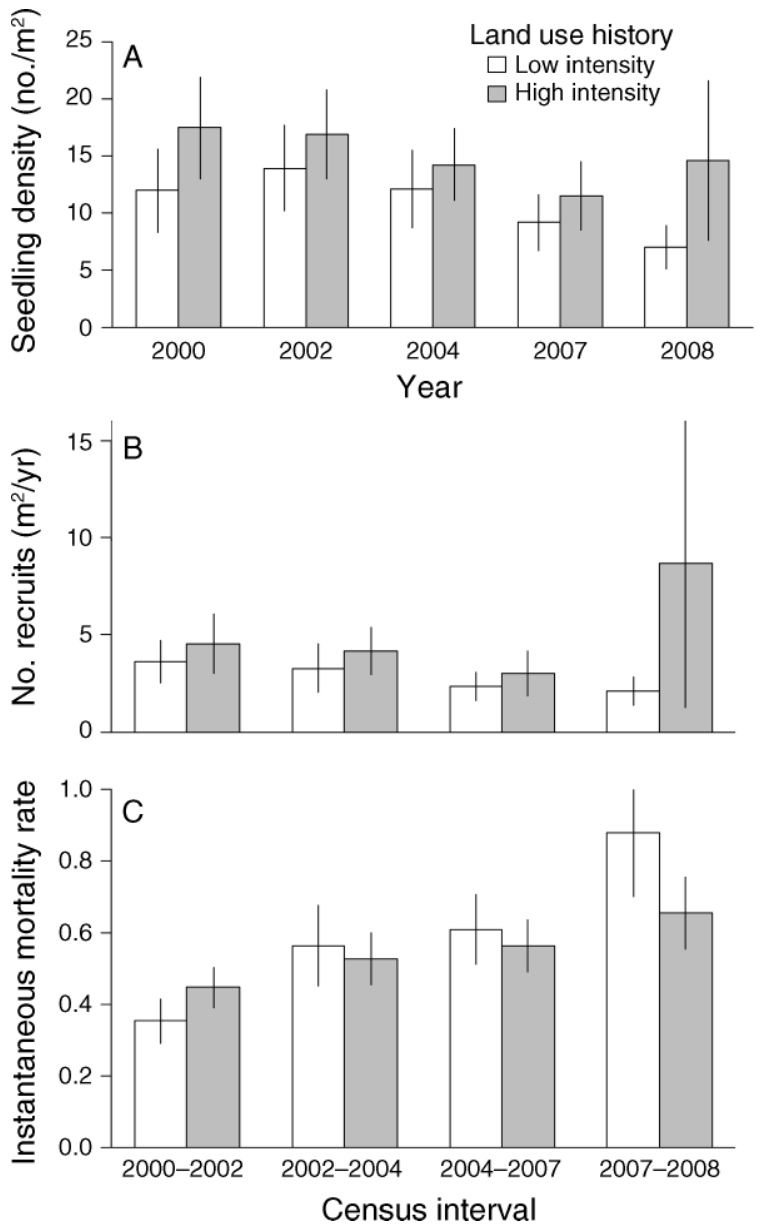

FIG. 3. (A) Seedling density, (B) recruitment, and (C) mortality rates (mean $\pm 2 \mathrm{SE}$ ) in each census of seedlings in the high- and low-intensity land use history areas of the Luquillo Forest Dynamics Plot, Puerto Rico. Instantaneous mortality rates were calculated as $\ln (N / S) /$ time, where $N$ is the number of seedlings at the start of the census interval and $S$ is the number that survived.

Peart 2003). For the height growth model, individual was included as a random effect because we had repeated measurements of some individuals. The most parsimonious models were determined using Akaike's information criterion (AIC) to compare models of differing complexity. For the RGR analysis, AIC values were calculated based on linear mixed models fit by maximum likelihood (Venables and Ripley 2002). All analyses were performed using $\mathrm{R}$ version 2.9.0 ( $\mathrm{R}$ Development Core Team 2009). Dissimilarity indices were calculated using the "vegan" package (Oksanen et al. 2009), and mixed models were carried out using the "lme4" package for R (Bates and Maechler 2009).

\section{RESULTS}

\section{Understory light conditions}

Canopy openness varied over time $(F=189.6, \mathrm{df}=3$, $566, P<0.001)$ and differed between the high-intensity and low-intensity historical land use categories $(F=29.6$, $\mathrm{df}=1,566, P<0.001)$, with a significant interaction between census year and land use history $(F=16.1, \mathrm{df}=$ $3,566, P<0.001$; Fig. 2). As expected, mean canopy openness was highest in March 1999 at the first measurement after Hurricane Georges, when compared to later censuses. In addition, percent canopy openness was significantly higher in the area of the plot that had been subjected to high-intensity land use in the 1920s and 1930s. This difference was particularly pronounced in 1999 (Fig. 2), when canopy openness values were not only higher, but also significantly more variable among plots, in the high-intensity land use area compared to the low-intensity land use area $(F=0.45, \mathrm{df}=48,100, P=$ $0.011)$.

\section{Seedling density and dynamics}

Seedling densities varied over time $(F=7.72, \mathrm{df}=4$, $740, P<0.001)$ and with land use history $(F=7.79, \mathrm{df}=$ 1, 740, $P=0.005$ ), but there was no significant interaction between the two variables $(F=0.54, \mathrm{df}=4$, $740, P=0.71)$. Densities were consistently higher in the portion of the plot that had been historically subjected to high-intensity land use (Fig. 3A), although post hoc tests for differences between the land use categories for individual censuses were not significant (all $P>0.05$ ). In the high-intensity land use category, seedling densities were highest in the first two censuses following Hurricane Georges, and then declined over subsequent censuses until there was an increase in density in 2008 (Fig. 3A). This apparent surge in seedling numbers in 2008, however, was driven by the recruitment of $\sim 600$ seedlings of one species (Prestoea acuminata) into a single seedling plot, and does not reflect the communitywide pattern. When this plot was removed from the analysis, seedling density in the high-intensity land use area declined across each census interval, but remained significantly higher than in the low-intensity area $(P=$ $0.007)$. In contrast, in the low-intensity land use category, seedling densities were highest approximately 3-4 years following Hurricane Georges (Fig. 3A).

Seedling recruitment rates were also significantly affected by both land use history $(F=4.05, \mathrm{df}=1$, 592, $P=0.04)$ and time of the census interval relative to Hurricane Georges $(F=2.78, \mathrm{df}=3,592, P=0.04)$, with no significant time $\times$ land use history interaction $(F=$ $1.70, \mathrm{df}=3,592, P=0.16$ ). Recruitment rates were significantly higher in the high-intensity land use portion of the plot compared to the low-intensity area over all years (Fig. 3B), although differences between land use history categories were not statistically significant when each census interval was tested independently (all $P>$ 0.05 ). Recruitment tended to decline with time after the hurricane, except for the recruitment pulse in 2008 in the high-intensity land use area (Fig. 3B). As with seedling density, this pattern was due to high recruitment of a single species in one seedling plot. 
TABLE 1. Number of seedlings and species encountered, and the diversity of the seedling layer by land use history category (lowintensity vs. high-intensity use) in the Luquillo Forest Dynamics Plot, Puerto Rico.

\begin{tabular}{|c|c|c|c|c|c|c|c|c|}
\hline \multirow[b]{2}{*}{ Year } & \multicolumn{2}{|c|}{ No. seedlings } & \multicolumn{2}{|c|}{ Total no. species } & \multicolumn{2}{|c|}{$\begin{array}{l}\text { Diversity per area } \\
\text { (10 seedling plots) }\end{array}$} & \multicolumn{2}{|c|}{$\begin{array}{c}\text { Diversity per individual } \\
\text { (100 individuals) }\end{array}$} \\
\hline & $\begin{array}{c}\text { Low } \\
\text { intensity }\end{array}$ & $\begin{array}{c}\text { High } \\
\text { intensity }\end{array}$ & $\begin{array}{c}\text { Low } \\
\text { intensity }\end{array}$ & $\begin{array}{c}\text { High } \\
\text { intensity }\end{array}$ & $\begin{array}{c}\text { Low } \\
\text { intensity }\end{array}$ & $\begin{array}{c}\text { High } \\
\text { intensity }\end{array}$ & $\begin{array}{c}\text { Low } \\
\text { intensity }\end{array}$ & $\begin{array}{c}\text { High } \\
\text { intensity }\end{array}$ \\
\hline 2000 & 1170 & 3533 & 52 & 68 & $33.5(27-40)$ & $32.1(24-40)$ & $28.5(23-33)$ & $24.0(19-29)$ \\
\hline 2002 & 1366 & 3412 & 49 & 64 & $31.9(24-39)$ & $30.4(23-37)$ & $25.5(20-30)$ & $21.7(17-27)$ \\
\hline 2004 & 1182 & 2875 & 52 & 62 & $28.3(20-36)$ & $25.6(19-32)$ & $23.4(19-29)$ & $19.2(15-24)$ \\
\hline 2007 & 896 & 2312 & 47 & 57 & $26.1(18-35)$ & $22.7(16-29)$ & $24.7(20-30)$ & $18.7(14-24)$ \\
\hline 2008 & 684 & 2945 & 48 & 54 & $24.8(16-34)$ & $22.5(16-29)$ & $26.7(22-32)$ & $16.7(12-21)$ \\
\hline
\end{tabular}

Notes: Forty-nine $2 \times 1 \mathrm{~m}$ seedling plots were censused in the low-intensity area, and 151 plots in the high-intensity area. Diversity was calculated as the mean number of species in a random sample of 10 seedlings plots (per area) and 100 individuals (per individual). Numbers in parentheses are $95 \%$ confidence intervals.

There was a significant effect of census interval on seedling mortality rates $(F=10.2$, df $=3,587, P<$ $0.001)$, with mortality increasing with time after hurricane disturbance (Fig. 3C). The effect of land use history on seedling mortality was less clear $(F=1.33$, df $=1,587, P=0.25)$, and varied significantly with census interval (interaction term: $F=3.17$, df $=3,587, P=$ $0.02)$. In the first census interval following the hurricane (census interval 2000-2002), mortality was higher in the high-intensity land use area than in the low-intensity area, while in subsequent intervals this pattern was reversed (Fig. 3C). Relative height growth rates also varied significantly over time $(F=13.5, \mathrm{df}=3,558, P<$ $0.001)$, with rates highest in the first census interval (2000-2002). However, growth did not vary between land use history categories overall $(F=1.39$, df $=1,558$, $P=0.24$ ) or for any individual census interval (all $P>$ $0.3)$.

\section{Species diversity and community composition}

More species were encountered in the seedling plots of the high-intensity land use area compared to the lowintensity area (Table 1). However, this was due to the greater number of seedling plots (101 vs. 49 plots) and the higher density of seedlings in the high-intensity land use portion of the LFDP (Fig. 2). Estimates of diversity based on rarefaction, which adjusted for differences in sampling effort and seedling density, indicated that the low-intensity land use area was consistently more diverse than the high-intensity portion of the LFDP on both a per area and per individual basis (Table 1). In both land use history categories, diversity on a per area basis declined over time, presumably due to decreasing seedling densities. On a per individual basis, diversity also declined over time in the high-intensity area, but not in the low-intensity area (Table 1).

In both the low- and high-intensity land use history areas of the plot, the seedling layer was consistently dominated by two species: Prestoea acuminata, the common palm species that does well in secondary forest, and Guarea guidonia, a late-successional tree species (Table 2). In the area of the plot that had experienced high-intensity land use in the past, Inga laurina, a secondary-forest species, was consistently the third most common species in the seedling layer. Aside from these three species, the relative abundance and ranking of the remaining species varied considerably among censuses in both land use history categories. Overall, community composition was more consistent over time in the area with a low intensity of past land use, as indicated by relatively low values of Morisita's index of dissimilarity (Table 3A). In contrast, in the high-intensity land use area, there was high dissimilarity in community composition between the initial census in 2000 and the census conducted two years later (Table 3B). After 2002, however, values for community dissimilarity between consecutive censuses were low, indicating that the major shift in species composition occurred between the first and second censuses.

When comparing seedling species composition between the two land use history categories, dissimilarity was high in the initial census, but was substantially lower in later censuses (Table 3C). In any given census, the two land use history categories had $40-60 \%$ overlap in the top 10 most common species (Table 2). Nonetheless, there were several species that were only ever in the top 10 ranked species of the low-intensity land use area (Sloanea berteriana, Manilkara bidentata, Eugenia domingensis Berg), and several only in the top 10 ranked species of the high-intensity land use area (Piper glabrescens (Miq.) C. DC., Tabebuia heterophylla, Syzygium jambos (L.) Alston, Ocotea sintenisii (Mez) Alain).

When examining changes in relative abundance of the 12 focal species of known successional status, the relative abundances of the late-successional and secondary-forest focal species groups were initially similar in both land use history categories (Fig. 4A). However, over time, the secondary-forest species group increased in relative abundance in the community, particularly in the portion of the plot with a history of high-intensity land use, while the late-successional species group appeared to be declining across most census intervals. However, this pattern was mainly driven by changes in the relative abundances of the two most common species in the seedling layer: the secondary-forest species 
TABLE 2. Ranked relative abundances over time of the most common species in the seedling layer in areas of the Luquillo Forest

Dynamics Plot that were subject to (A) low-intensity and (B) high-intensity human land use in the first half of the 20th century.

\begin{tabular}{|c|c|c|c|c|c|c|}
\hline \multirow[b]{2}{*}{ Rank } & \multicolumn{2}{|c|}{2000} & \multicolumn{2}{|c|}{2002} & \multicolumn{2}{|c|}{2004} \\
\hline & Species & Rel. abund. & Species & Rel. abund. & Species & Rel. abund. \\
\hline
\end{tabular}

A) Low-intensity land use history

$\begin{array}{rll}1 & \text { Prestoea acuminata } & 0.289 \\ 2 & \text { Guarea guidonia } & 0.173 \\ 3 & \text { Sapium laurocerasus } & 0.044 \\ 4 & \text { Sloanea berteriana } & 0.035 \\ 5 & \text { Manilkara bidentata } & 0.034 \\ 6 & \text { Dacryodes excelsa } & 0.027 \\ 7 & \text { Schefflera morototoni } & 0.025 \\ 8 & \text { Matayba domingensis } & 0.022 \\ 9 & \text { Eugenia domingensis } & 0.021 \\ 10 & \text { Inga laurina } & 0.021 \\ & \text { Psychotria berteroana } & 0.021\end{array}$

Prestoea acuminata
Guarea guidonia
Dacryodes excelsa
Tetragastris balsamifera
Psychotria berteroana
Manilkara bidentata
Eugenia domingensis
Schefflera morototoni
Sloanea berteriana
Inga laurina
Ocotea leucoxylon

0.389
0.133
0.070
0.041
0.031
0.024
0.023
0.021
0.020
0.016
0.016

$\begin{array}{ll}\text { Prestoea acuminata } & 0.484 \\ \text { Guarea guidonia } & 0.074 \\ \text { Dacryodes excelsa } & 0.061 \\ \text { Tetragastris balsamifera } & 0.047 \\ \text { Inga laurina } & 0.046 \\ \text { Eugenia domingensis } & 0.027 \\ \text { Sloanea berteriana } & 0.024 \\ \text { Manilkara bidentata } & 0.018 \\ \text { Psychotria brachiata } & 0.015 \\ \text { Psychotria berteroana } & 0.014 \\ \text { Psychotria deflexa } & 0.014\end{array}$

B) High-intensity land use history

$\begin{array}{rlllll}1 & \text { Guarea guidonia } & 0.293 & \text { Prestoea acuminata } & 0.377 & \text { Prestoea acuminata } \\ 2 & \text { Prestoea acuminata } & 0.142 & \text { Guarea guidonia } & 0.175 & \text { Guarea guidonia } \\ 3 & \text { Inga laurina } & 0.094 & \text { Inga laurina } & 0.087 & \text { Inga laurina } \\ 4 & \text { Psychotria berteroana } & 0.074 & \text { Syzygium jambos } & 0.036 & \text { Syzygium jambos } \\ 5 & \text { Piper glabrescens } & 0.040 & \text { Piper glabrescens } & 0.033 & \text { Ocotea leucoxylon } \\ 6 & \text { Tabebuia heterophylla } & 0.037 & \text { Psychotria berteroana } & 0.033 & \text { Piper glabrescens } \\ 7 & \text { Psychotria brachiata } & 0.026 & \text { Tabebuia heterophylla } & 0.028 & \text { Trichilia pallida } \\ 8 & \text { Sapium laurocerasus } & 0.023 & \text { Ocotea leucoxylon } & 0.025 & \text { Ocotea sintenisii } \\ 9 & \text { Byrsonima spicata } & 0.023 & \text { Ocotea sintenisii } & 0.019 & \text { Dacryodes excelsa } \\ 10 & \text { Schefflera morototoni } & 0.022 & \text { Dacryodes excelsa } & 0.019 & \text { Tabebuia heterophylla } \\ \end{array}$

Prestoea acuminata, which increased in relative abundance, and the late-successional species Guarea guidonia, which declined in relative abundance over time, particularly in the high-intensity land use area (Fig. 4B). When these two species were excluded, there was no clear trend over time in the relative abundances of late-successional vs. secondary-forest species (Fig. 4C).

\section{Successional status and species dynamics}

The change over time in seedling densities of the 12 focal species in both land use history categories showed a variety of patterns (Fig. 5), some of which could be explained by species' successional status. As expected, late-successional species tended to be found at higher densities in the portion of the LFDP with a low intensity of historical land use (Fig. 5A-E), while secondaryforest and pioneer species were typically more dense in the high historical land use intensity area (Fig. 5F-L), reflecting the relative distribution of adult trees. One exception was the late-successional species Guarea guidonia, which had a greater density of seedlings in the high-intensity area than in the low-intensity area (Fig. 5E). The majority of species showed a decline in seedling density as time passed after Hurricane Georges, with the pioneer species, Cecropia schreberiana and Scheflerra morototoni, and the secondary-forest species, Alchornea latifolia, showing the most dramatic drops in seedling density. However, seedling densities of several

TABLE 3. Community dissimilarity among years in areas of the Luquillo Forest Dynamics Plot with a history of (A) low-intensity and (B) high-intensity human land use, and (C) dissimilarity in species composition between the two land use history categories in each census year.

\begin{tabular}{|c|c|c|c|c|c|}
\hline Year & 2000 & 2002 & 2004 & 2007 & 2008 \\
\hline \multicolumn{6}{|c|}{ A) Low-intensity historical land use } \\
\hline 2002 & 0.049 & & & & \\
\hline 2004 & 0.141 & 0.030 & & & \\
\hline 2007 & 0.132 & 0.032 & 0.038 & & \\
\hline 2008 & 0.075 & 0.013 & 0.019 & 0.043 & \\
\hline \multicolumn{6}{|c|}{ B) High-intensity historical land use } \\
\hline 2002 & 0.231 & & & & \\
\hline 2004 & 0.350 & 0.022 & & & \\
\hline 2007 & 0.263 & 0.010 & 0.013 & & \\
\hline 2008 & 0.387 & 0.048 & 0.016 & 0.029 & \\
\hline \multicolumn{6}{|c|}{ C) Low vs. high-intensity } \\
\hline Dissimilarity & 0.197 & 0.039 & 0.038 & 0.093 & 0.051 \\
\hline
\end{tabular}

Note: Dissimilarity values were calculated using the Morisita index. 
TABLE 2. Extended.

\begin{tabular}{|c|c|c|c|}
\hline \multicolumn{2}{|c|}{2007} & \multicolumn{2}{|c|}{2008} \\
\hline Species & Rel. abund. & Species & Rel. abund. \\
\hline Prestoea acuminata & 0.394 & Prestoea acuminata & 0.408 \\
\hline Dacryodes excelsa & 0.154 & Guarea guidonia & 0.099 \\
\hline Guarea guidonia & 0.068 & Tetragastris balsamifera & 0.047 \\
\hline Tetragastris balsamifera & 0.038 & Ocotea leucoxylon & 0.032 \\
\hline Eugenia domingensis & 0.025 & Manilkara bidentata & 0.029 \\
\hline Ocotea leucoxylon & 0.023 & Roystonea borinquena & 0.029 \\
\hline Manilkara bidentata & 0.022 & Dacryodes excelsa & 0.026 \\
\hline Sloanea berteriana & 0.022 & Sloanea berteriana & 0.025 \\
\hline Roystonea borinquena & 0.020 & Eugenia domingensis & 0.023 \\
\hline Inga laurina & 0.019 & Inga laurina & 0.023 \\
\hline Psychotria brachiata & 0.019 & Psychotria deflexa & 0.023 \\
\hline Prestoea acuminata & 0.406 & Prestoea acuminata & 0.520 \\
\hline Guarea guidonia & 0.189 & Guarea guidonia & 0.164 \\
\hline Inga laurina & 0.109 & Inga laurina & 0.093 \\
\hline Dacryodes excelsa & 0.045 & Ocotea leucoxylon & 0.033 \\
\hline Ocotea leucoxylon & 0.041 & Roystonea borinquena & 0.021 \\
\hline Piper glabrescens & 0.022 & Piper glabrescens & 0.017 \\
\hline Trichilia pallida & 0.022 & Trichilia pallida & 0.015 \\
\hline Casearia arborea & 0.016 & Ocotea sintenisii & 0.013 \\
\hline Syzygium jambos & 0.015 & Tetragastris balsamifera & 0.012 \\
\hline Ocotea sintenisii & 0.015 & Casearia arborea & 0.011 \\
\hline
\end{tabular}

late-successional species (Dacryodes excelsa and Tetragastis balsamifera) and secondary-forest species (Prestoea acuminata, Inga laurina, and Casearia arborea) reached their highest densities in later censuses.
Seedling dynamics of the late-successional and secondary-forest focal species groups were differentially impacted by hurricane disturbance and land use history. The most parsimonious model for seedling
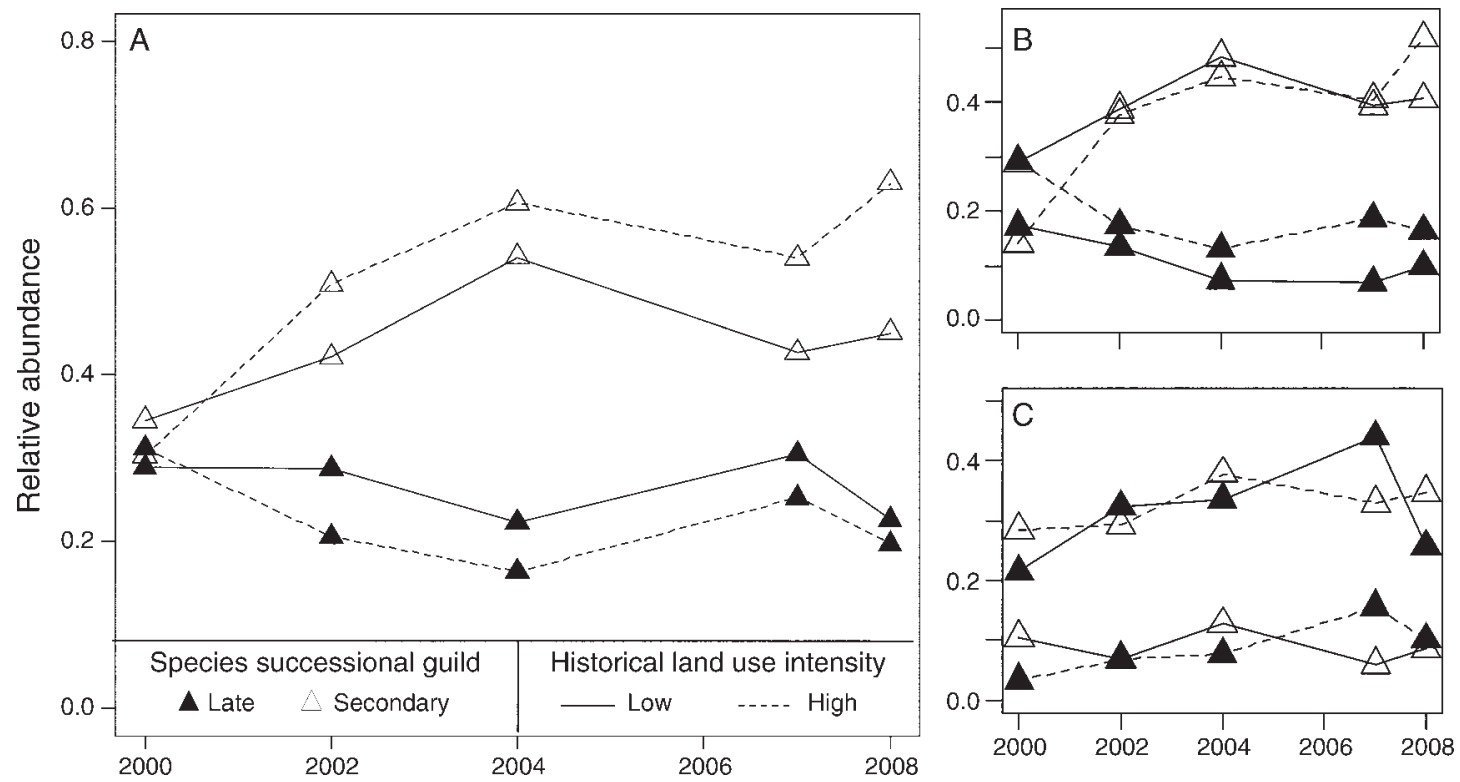

FIG. 4. Relative abundance of late-successional (solid triangles) and secondary-forest (open triangles) species in the areas of the Luquillo Forest Dynamics Plot with a low intensity (solid line) and high intensity (dashed line) of past human land use. Late successional species are: Dacryodes excelsa, Manilkara bidentata, Sloanea berteriana, Tetragastris balsamifera, and Guarea guidonia; secondary forest species are: Casearia arborea, Prestoea acuminata var. montana, Inga laurina, Tabebuia heterophylla, and Alchornea latifolia. (A) Relative abundance of the five focal species combined for each species group. (B) Relative abundances of Guarea guidonia (solid triangles) and Prestoea acuminata (open triangles), the most common species in the late-successional and secondaryforest species groups, respectively. (C) Relative abundances of the two species groups after excluding G. guidonia and $P$. acuminata. 

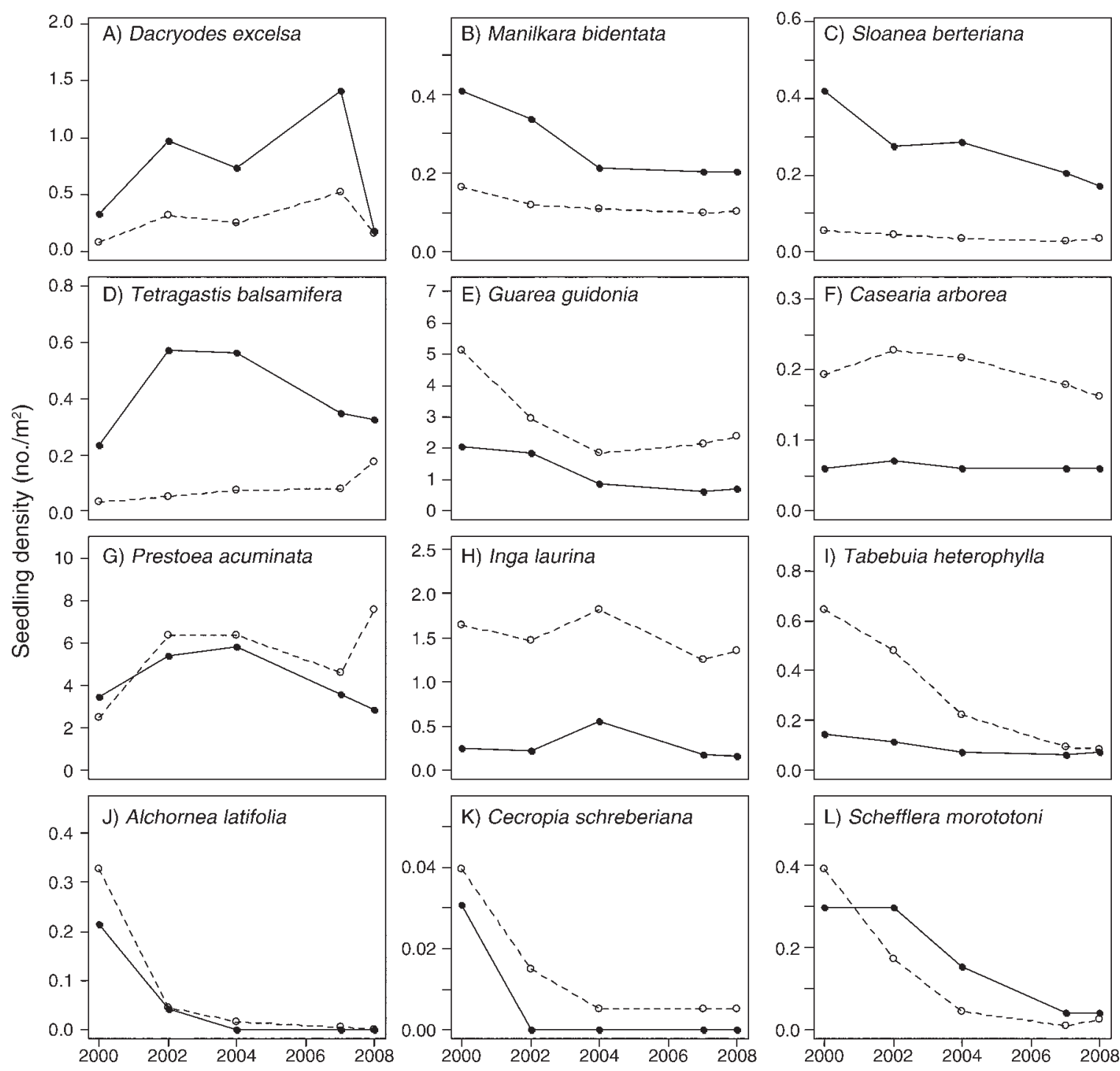

FIG. 5. Seedling densities of the 12 focal species in each census in areas of the Luquillo Forest Dynamics Plot with a low intensity (solid line) and high intensity (dashed line) of past human land use. Species in panels A-E are classified as late-successional species, in panels $\mathrm{F}-\mathrm{J}$ as secondary-forest species, and panels $\mathrm{K}-\mathrm{L}$ as pioneer species.

survival included successional status, hurricane disturbance, and land use history, and all two- and three-way interactions between those variables (Table 4). For seedlings of both late-successional and secondary-forest species, the probability of survival was higher in the census interval immediately following Hurricane Georges, when the canopy was more open, compared to subsequent intervals when the forest canopy had largely recovered from hurricane damage (Fig. 6A, B). The probability of seedling survival following hurricane disturbance was considerably higher for secondaryforest species in the area of the plot that had only experienced a low intensity of historical land use (Fig. 6B), contrary to the expectation that seedlings of secondary-forest species would benefit from the higher canopy openness in the area with high-intensity past land use.

Seedlings of secondary-forest species also responded more strongly than late-successional species to hurricane disturbance in terms of height growth (Fig. 6C, D). As with survival, seedling relative growth rates for both late-successional and secondary-forest species were higher in the first census interval following Hurricane Georges compared to subsequent intervals, particularly in the area with a low intensity of historical land use (Fig. 6C, D). However, the most parsimonious model for growth did not include an interaction between successional status and land use history (Table 4), indicating that growth rates of the two species groups were similarly affected by land use history. 
TABLE 4. Comparison of AIC values for mixed-effects models of seedling survival and relative growth rate.

\begin{tabular}{lcc}
\hline \hline & \multicolumn{2}{c}{ AIC values } \\
\cline { 2 - 3 } \multicolumn{1}{c}{ Interaction terms in model } & $\begin{array}{c}\text { Survival } \\
\text { model }\end{array}$ & $\begin{array}{c}\text { Growth } \\
\text { model }\end{array}$ \\
\hline All two- and three-way interactions & $\mathbf{1 1 5 2 5 . 8}$ & -964.5 \\
All two-way interactions & 11529.6 & -965.8 \\
SUCC $\times$ HURR + HIST $\times$ HURR & 11533.9 & $\mathbf{- 9 6 7 . 8}$ \\
SUCC $\times$ HIST + SUCC $\times$ HURR & 11564.2 & -964.1 \\
SUCC $\times$ HIST + HIST $\times$ HURR & 11532.9 & -947.2 \\
SUCC $\times$ HURR & 11565.2 & -966.0 \\
HIST $\times$ HURR & 11537.5 & -949.1 \\
SUCC $\times$ HIST & 11567.2 & -946.4 \\
No interactions & 11568.4 & -948.4 \\
\hline
\end{tabular}

Notes: Models include effects of species' successional status (SUCC), hurricane disturbance (HURR), and land use history (HIST), as well as interactions between those three factors. The lowest AIC value for each set of models (in bold) indicates the most parsimonious model.

\section{Discussion}

\section{Effect of land use history on seedling density and dynamics}

We found that the effect of hurricane disturbance on forest regeneration at the seedling stage is significantly altered by land use history. Changes in the density and dynamics of the seedling layer following Hurricane Georges were more dramatic in areas that had been subjected to a high intensity of past human land use. Differences in seedling density and dynamics between the land use history categories are likely due in part to differences in understory light conditions. In the northern portion of the LFDP, which had experienced a high intensity of human land use in the past, we found significantly greater canopy openness compared to the southern area, which had experienced only light selective logging. This difference was particularly pronounced at the first measurement following Hurricane Georges, probably because secondary-forest species that dominate the canopy in the highly human-impacted area are more susceptible to damage during hurricanes (Zimmerman et al. 1994). The pattern of greater canopy openness in the high vs. low land use intensity area persisted in later censuses, due either to slower recovery of the forest canopy in the high-intensity land use area or to differences in branching and leaf architecture of secondary- vs. primary-forest species.

Higher understory light levels in the high-intensity land use area likely drove the pattern of higher seedling densities in that part of the LFDP. In tropical forests, seedlings growing under intact canopies are typically

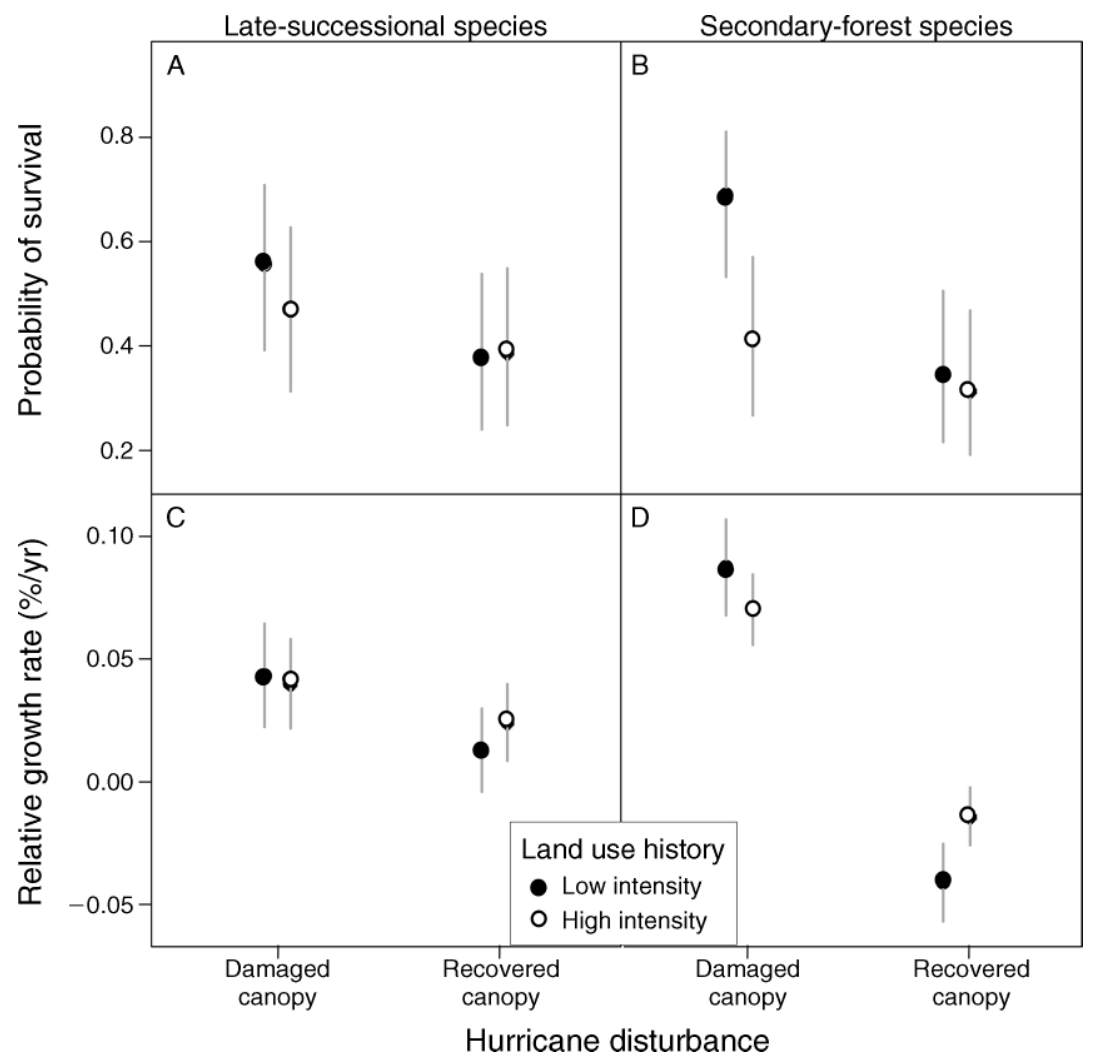

FIG. 6. Seedling survival and growth (mean $\pm \mathrm{SE})$ of $(\mathrm{A}, \mathrm{C})$ late-successional and $(\mathrm{B}, \mathrm{D})$ secondary-forest species groups in areas with low and high historical land use intensity and with hurricane-damaged and recovered forest canopy. Estimated probabilities of survival (for a seedling of average height) and relative growth rates (RGR) are based on results of full generalized linear and linear mixed models, respectively. 
light-limited (Chazdon et al. 1996), and higher light levels usually increase seed germination, seedling growth, survival, and density (Everham et al. 1996, Montgomery and Chazdon 2002, Barberis and Tanner 2005). Our analyses of seedling dynamics revealed that the higher seedling densities in the high-intensity historical land use area were due to both higher recruitment and survival in that area of the LFDP over much of the study. The one exception was during the initial census interval, in which survival was lower in the high-intensity land use area. This may have been due to density-dependent mortality thinning out high-density patches, or to desiccation or sun scald of seedlings growing under more open canopies (e.g., Gerhardt 1996). This is consistent with a previous study in which we found that seedling survival in the Luquillo plot increased with increasing canopy openness at low to medium levels, but decreased at higher levels (Comita et al. 2009).

\section{Land use history and species composition of the seedling layer}

The seedling layer in both land use history categories was dominated by two species, Prestoea acuminata and Guarea guidonia. The high seedling density of $P$. acuminata is not surprising given that it is the most abundant species $\geq 10 \mathrm{~cm}$ dbh in the LFDP (Thompson et al. 2002). In tabonuco forest, this palm species appears to thrive following human disturbance. Adult trees are particularly abundant in the area of the LFDP that had been clear cut in the 1920s (Thompson et al. 2002), and this species has also been found to be associated with charcoal production in another tabonuco forest site in Puerto Rico (García-Montiel and Scatena 1994). In addition, P. acuminata appears to be well-adapted to hurricane disturbance (Canham et al. 2009). Adult trees of the species experience low mortality and rapid recovery following hurricanes, and $P$. acuminata seedlings show increased survival and growth rates in response to higher light availability under hurricane-damaged canopies (Zimmerman and Covich 2007, Comita et al. 2009).

Although considered a late-successional species, $G$. guidonia seedlings were also exceptionally abundant in both land use history categories. Guarea guidonia seedlings are known to be shade tolerant, but have been found to show increased growth and survival in hurricane-disturbed compared to undisturbed sites in Puerto Rico and may depend on canopy disturbance for successful regeneration (Sustache 2004). The surprisingly high abundance of this species in the seedling layer of the high-intensity land use history area is likely due to the fact that part of that area had been used to grow coffee in the 1920s (Thompson et al. 2002). In Puerto Rico, G. guidonia was often associated with coffee cultivation, along with leguminous species Inga vera and Inga laurina (García-Montiel and Scatena 1994), and tends to increase in abundance following abandonment of coffee plantations (Weaver and Birdsey 1986). This illustrates the fact that forest composition is influenced not only by the intensity, but also the type of past land use, and that the resulting signature on species' abundances can often be idiosyncratic (Rivera et al. 2000, Grau et al. 2003, Uriarte et al. 2004b).

In addition to $P$. acuminata and $G$. guidonia, several species tended to be relatively common in the seedling layer of both the high- and low-intensity land use history areas. Furthermore, values of Morisita's index of dissimilarity suggest that overall species composition was quite similar in the two areas, with the exception of the initial census after Hurricane Georges. In fact, differences in species composition between the land use areas were similar to, or less than, changes within each of the areas over the course of the study. Nonetheless, clear differences in composition between the two land use history areas were found. The majority of common species were among the top 10 most abundant species in only the high-intensity or only the low-intensity historical land use area. In addition, of the focal species of known successional status, the late-successional species were typically more abundant in the lowintensity land use history area, while the secondaryforest species were typically more abundant in the highintensity land use history area. The low-intensity land use history area also consistently supported a higher diversity of species, both per unit area and per individual. These patterns reflect the distribution and diversity for trees $\geq 10 \mathrm{~cm}$ dbh in the LFDP: Thompson et al. (2002) found that the least human-impacted portion of the LFDP supported the highest species richness, and number of rare and endemic species, and had higher densities of late-successional species. Thus, differences between land use history categories in seedling composition and diversity are likely driven in part by the spatial distribution of reproductive adult trees combined with local seed dispersal (Uriarte et al. 2005).

In the high-intensity land use history area, diversity of the seedling layer peaked in the first census following Hurricane Georges and then dropped over time. Hurricane disturbance increased not only the mean, but also the variance in canopy openness in the highintensity land use portion of the LFDP, providing a wider range of light conditions that may have temporarily supported a more diverse assemblage of species with increased representation of light-demanding pioneer species in the seedling layer. However, as the canopy closed, seedlings of more light-demanding species died off. Over time, the dominance of a few species increased, causing a drop in diversity in the highintensity land use history area.

\section{Hurricane disturbance and land use legacies}

It has been hypothesized that hurricanes could prolong human land use legacies by creating conditions that promote the regeneration of secondary-forest 


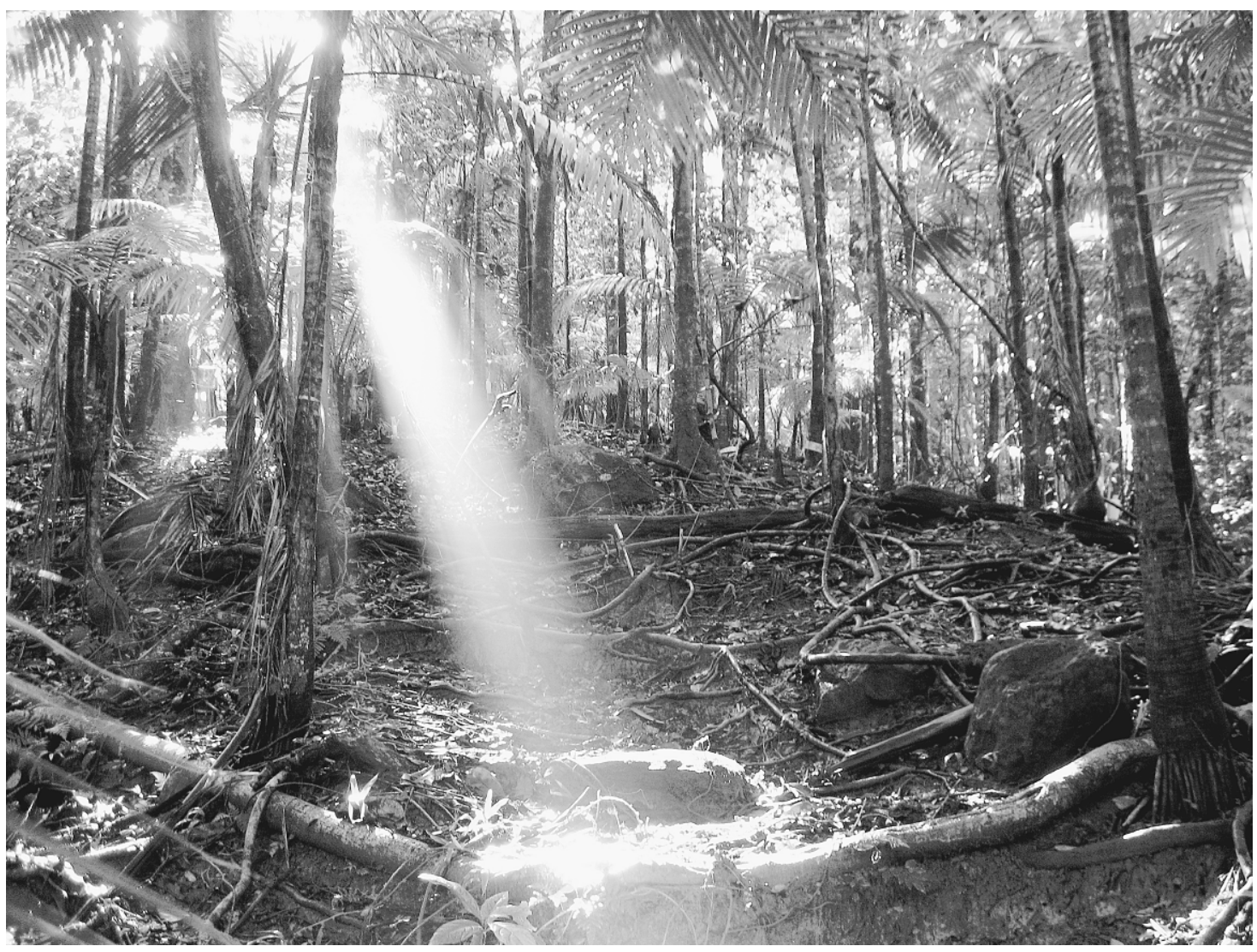

Plate 1. Sunlight hitting the forest floor in the Luquillo Experimental Forest, Puerto Rico. Photo credit: John Bithorn.

species (Uriarte et al. 2009). Consistent with this, we found that secondary-forest species exhibited higher seedling growth and survival following hurricane disturbance, and that the response of secondary-forest species to hurricanes was greater than that of latesuccessional species. This likely reflects the overlap between traits that allows species to colonize or thrive following human disturbance and traits that give species an advantage following hurricane disturbance (Foster et al. 1998b, Pascarella et al. 2004, Uriarte et al. 2004a). In particular, species that are able to survive well, and increase growth rates under high light conditions, should prosper following both human and hurricane-mediated disturbance. For this reason, we expected seedlings of secondary-forest species to perform best in the highintensity historical land use area because canopy openness was highest in that area. However, the increase in performance due to hurricane disturbance occurred predominantly in the area of the plot that had only experienced a low intensity of past human disturbance. As noted earlier, this may be due to sun scald or desiccation of seedlings growing under more open canopy in the high-intensity land use history area. Thus, while we found evidence that hurricanes promote the regeneration of seedlings of secondary-forest species, contrary to our expectations, this effect was not amplified in areas dominated by adult trees of these species.

The pioneer species $C$. schreberiana and $S$. morototoni and the light-demanding secondary-forest species $A$. latifolia (which is considered a pioneer in some studies, e.g., Walker et al. 2003) did show elevated seedling densities in the high-intensity land use history area in the first census following Hurricane George, suggesting that they are capable of tolerating post-hurricane conditions in that area. In subsequent censuses, however, these species declined drastically in the seedling layer, suggesting that pioneers play a limited role in forest recovery following hurricane disturbance, consistent with observations in previous studies (Chazdon 2003).

Our results suggest that the greater damage and mortality of adult trees of secondary-forest species during hurricanes is not offset by enhanced recruitment of their seedlings in human-impacted secondary forests. This suggests that the net effect of hurricanes in highly human-impacted forests is to reduce the abundance of secondary-forest species, consistent with the hypothesis that hurricanes help erase the signature of past land use (Zimmerman et al. 1994, Ogle et al. 2006). However, hurricanes do appear to promote the regeneration of seedlings of secondary-forest species in areas that have had little direct human disturbance, potentially increas- 
ing the abundance of secondary-forest species in less human-impacted areas. Seeds of secondary-forest species are probably able to arrive at and win sites in these less human-impacted areas at a higher frequency than before human disturbance because human disturbance has resulted in an elevated abundance of reproductive adults of these species across the landscape, thereby decreasing recruitment limitation.

Future forest composition will not be identical to that of the seedling layer, but rather will be determined by multiple processes that act on seedlings and saplings to influence which individuals and species ultimately win a place in the canopy. The relative importance of the short term $(<5$ year) effects of hurricane disturbance on seedling dynamics shown here, compared to other factors, is not yet known. Based on our current results, it appears that hurricanes may act to homogenize differences in species composition between areas with differing land use histories by promoting the regeneration of secondary-forest species in less human-impacted areas. This idea is further supported by the results of a forest simulator constructed using 15 years of data on sapling and tree dynamics in the Luquillo forest (SORTIE-PR; Uriarte et al. 2009), which predicted that hurricanes will increase the community similarity of areas with differing land use histories and that the Luquillo forest will become an increasingly homogenous mix of both primary- and secondary-forest species.

Given the increasing extent and importance of human-impacted forests in the tropics (ITTO 2002, Chazdon 2003, FAO 2005), there is a pressing need to understand the landscape- and stand-level processes that will determine the composition of these communities. Understanding the responses of each life history stage to past land use is a critical component of predicting and managing secondary-forest recovery in the tropics. Previous studies have found that past human land use can continue to have a signature on species composition of forests for centuries (Finegan 1996). Our results suggest that through effects on seedling regeneration, hurricanes may extend the signature of land use history beyond the average recovery time of forests that are not subject to such intense natural disturbance events. These effects may be amplified in the future given predicted increases in hurricane intensity and frequency (Emanuel 2005, Webster et al. 2005, Holland and Webster 2007). The challenge now is to determine the implications of changes in species composition in primary forest, and a prolonged recovery from human disturbance in secondary forest for ecosystem function and biodiversity conservation.

\section{ACKNOWLEDGMENTS}

This work was supported by NSF grants DEB-0614659, DEB-9906713, DEB-0087214, and DEB-0516066 to C. D. Canham, J. Thompson, J. Zimmerman, and M. Uriarte, and by the Andrew W. Mellon Foundation and the Center for Tropical Forest Science. Additional support was provided by grants from NSF to the Institute for Tropical Ecosystem Studies,
University of Puerto Rico, working with the International Institute of Tropical Forestry, for the Luquillo LTER Program. L. S. Comita acknowledges the support of an Earth Institute Fellowship from Columbia University. We thank the founders of the LFDP: R. B. Waide, D. J. Lodge, C. M. Taylor, and E. M. Everham III, and the LTER and LFDP technicians and volunteer assistants who worked on the seedling censuses.

\section{Literature Cited}

Barberis, I. M., and E. V. J. Tanner. 2005. Gaps and root trenching increase tree seedling growth in Panamanian semievergreen forest. Ecology 86:667-674.

Bates, D., and M. Maechler. 2009. lme4: linear mixed-effects models using S4 classes. R package version 0.999375-31. 〈http://cran.r-project.org/web/packages/lme4/index.html〉

Benjamini, Y., and Y. Hochberg. 1995. Controlling the false discovery rate: a practical and powerful approach to multiple testing. Journal of the Royal Statistical Society B 57:289-300.

Bolker, B. M., M. E. Brooks, C. J. Clark, S. W. Geange, J. R. Poulsen, M. H. H. Stevens, and J. S. S. White. 2009. Generalized linear mixed models: a practical guide for ecology and evolution. Trends in Ecology and Evolution 24:127-135.

Boose, E. R., D. R. Foster, and M. Fluet. 1994. Hurricane impacts to tropical and temperate forest landscapes. Ecological Monographs 64:369-400.

Boucher, D. H., J. H. Vandermeer, I. G. de la Cerda, M. A. Mallona, I. Perfecto, and N. Zamora. 2001. Post-agriculture versus post-hurricane succession in southeastern Nicaraguan rain forest. Plant Ecology 156:131-137.

Brokaw, N. V. L., and L. R. Walker. 1991. Summary of the effects of Caribbean hurricanes on vegetation. Biotropica 23: 442-447.

Burslem, D., and T. C. Whitmore. 1999. Species diversity, susceptibility to disturbance and tree population dynamics in tropical rain forest. Journal of Vegetation Science 10:767776.

Burslem, D. F. R. P., T. C. Whitmore, and G. C. Brown. 2000. Short-term effects of cyclone impact and long-term recovery of tropical rain forest on Kolombangara, Solomon Islands. Journal of Ecology 88:1063-1078.

Canham, C. D., J. Thompson, J. K. Zimmerman, and M. Uriarte. 2009. Variation in susceptibility to hurricane damage as a function of storm severity in Puerto Rican tree species. Biotropica 42:87-94.

Capers, R. S., R. L. Chazdon, A. R. Brenes, and B. V. Alvarado. 2005. Successional dynamics of woody seedling communities in wet tropical secondary forests. Journal of Ecology 93:1071-1084.

Catterall, C. P., S. McKenna, J. Kanowski, and S. D. Piper. 2008. Do cyclones and forest fragmentation have synergistic effects? A before-after study of rainforest vegetation structure at multiple sites. Austral Ecology 33:471-484.

Chazdon, R. L. 2003. Tropical forest recovery: legacies of human impact and natural disturbances. Perspectives in Plant Ecology, Evolution and Systematics 6:51-71.

Chazdon, R. L. 2008. Beyond deforestation: restoring forests and ecosystem services on degraded lands. Science 320:14581460.

Chazdon, R. L., R. W. Pearcy, D. W. Lee, and N. Fetcher. 1996. Photosynthetic responses of tropical forest plants to contrasting light environments. Pages 5-55 in S. S. Mulkey, R. L. Chazdon, and A. P. Smith, editors. Tropical forest plant ecophysiology. Chapman and Hall, New York, New York, USA.

Clark, D. B. 1996. Abolishing virginity. Journal of Tropical Ecology 12:735-739.

Comita, L. S., M. Uriarte, J. Thompson, I. Jonckheere, C. D. Canham, and J. K. Zimmerman. 2009. Abiotic and biotic drivers of seedling survival in a hurricane-impacted tropical forest. Journal of Ecology 97:1346-1359. 
Dambrine, E., J. L. Dupouey, L. Laut, L. Humbert, M. Thinon, T. Beaufils, and H. Richard. 2007. Present forest biodiversity patterns in France related to former Roman agriculture. Ecology 88:1430-1439.

Emanuel, K. 2005. Increasing destructiveness of tropical cyclones over the past 30 years. Nature 436:686-688.

Everham, E. M., III, and N. V. L. Brokaw. 1996. Forest damage and recovery from catastrophic wind. Botanical Review 62:113-185.

Everham, E. M., III, R. W. Myster, and E. VandeGenachte. 1996. Effects of light, moisture, temperature, and litter on the regeneration of five tree species in the tropical montane wet forest of Puerto Rico. American Journal of Botany 83:10631068.

Ewel, J. J., and J. L. Whitmore. 1973. The ecological life zones of Puerto Rico and the United States Virgin Islands. International Institute of Tropical Forestry, Rio Piedras, Puerto Rico.

FAO. 2005. Global forest resources assessment 2005: progress towards sustainable forest management. FAO Forestry Paper, Food and Agriculture Organization (United Nations), Rome, Italy.

Finegan, B. 1996. Pattern and process in Neotropical secondary rain forests: the first 100 years of succession. Trends in Ecology and Evolution 11:119-124.

Foster, D., M. Fluet, and E. Boose. 1998a. Human or natural disturbance: landscape-scale dynamics of the tropical forests of Puerto Rico. Ecological Applications 9:555-572.

Foster, D. R., G. Motzkin, and B. Slater. 1998b. Land-use history as long-term broad-scale disturbance: regional forest dynamics in central New England. Ecosystems 1:96-119.

Franklin, J., D. R. Drake, K. R. McConkey, F. Tonga, and L. B. Smith. 2004. The effects of Cyclone Waka on the structure of lowland tropical rain forest in Vava'u, Tonga. Journal of Tropical Ecology 20:409-420.

García-Montiel, D., and F. N. Scatena. 1994. The effect of human activity on the structure and composition of a tropical forest in Puerto Rico. Forest Ecology and Management 63: 57-78.

Gardner, T. A., J. Barlow, L. W. Parry, and C. A. Peres. 2007. Predicting the uncertain future of tropical forest species in a data vacuum. Biotropica 39:25-30.

Gauriguata, M. R., and R. Ostertag. 2001. Neotropical secondary forest succession: changes in structural and functional characteristics. Forest Ecology and Management 148:185-206.

Gerhardt, K. 1996. Effects of root competition and canopy openness on survival and growth of tree seedlings in a tropical seasonal dry forest. Forest Ecology and Management 82:33-48.

Gómez-Pompa, A., and A. Kaus. 1992. Taming the wilderness myth. BioScience 42:271-279.

Grau, H. R., T. M. Aide, J. K. Zimmerman, J. R. Thomlinson, E. Helmer, and X. M. Zou. 2003. The ecological consequences of socioeconomic and land-use changes in postagriculture Puerto Rico. BioScience 53:1159-1168.

Guariguata, M. R., R. L. Chazdon, J. S. Denslow, J. M. Dupuy, and L. Anderson. 1997. Structure and floristics of secondary and old-growth forest stands in lowland Costa Rica. Plant Ecology 132:107-120.

Holland, G. J., and P. J. Webster. 2007. Heightened tropical cyclone activity in the North Atlantic: natural variability or climate trend? Philosophical Transactions of the Royal Society A 365:2695-2716.

ITTO. 2002. ITTO guidelines for the restoration, management and rehabilitation of degraded and secondary tropical forests. International Tropical Timber Organization (ITTO) Policy Development Series Number 13, Yokohama, Japan.

Jonckheere, I., K. Nackaerts, B. Muys, and P. Coppin. 2005. Assessment of automatic gap fraction estimation of forests from digital hemispherical photography. Agricultural and Forest Meteorology 132:96-114.

Jonckheere, I., K. Nackaerts, B. Muys, J. van Aardt, and P. Coppin. 2006. A fractal dimension-based modelling approach for studying the effect of leaf distribution on LAI retrieval in forest canopies. Ecological Modelling 197:179 195.

Kauffman, J. B., R. F. Hughes, and C. Heider. 2009. Carbon pool and biomass dynamics associated with deforestation, land use, and agricultural abandonment in the Neotropics. Ecological Applications 19:1211-1222.

King, D. A., S. J. Davies, M. N. N. Supardi, and S. Tan. 2005. Tree growth is related to light interception and wood density in two mixed Dipterocarp forests of Malaysia. Functional Ecology 19:445-453.

Korner, C. 2004. Through enhanced tree dynamics carbon dioxide enrichment may cause tropical forests to lose carbon. Philosophical Transactions of the Royal Society B 359:493498.

Lugo, A. E. 2008. Visible and invisible effects of hurricanes on forest ecosystems: an international review. Austral Ecology 33:368-398.

Montgomery, R. A., and R. L. Chazdon. 2002. Light gradient partitioning by tropical tree seedlings in the absence of canopy gaps. Oecologia 131:165-174.

Muller-Landau, H. C. 2004. Interspecific and inter-site variation in wood specific gravity of tropical trees. Biotropica 36 : $20-32$.

Norden, N., R. L. Chazdon, A. Chao, Y. H. Jiang, and B. Vilchez-Alvarado. 2009. Resilience of tropical rain forests: tree community reassembly in secondary forests. Ecology Letters 12:385-394.

Ogle, K., M. Uriarte, J. Thompson, J. Johnstone, A. Jones, Y. Lin, E. McIntire, and J. Zimmerman. 2006. Implications of vulnerability to hurricane damage for long-term survival of tropical tree species: a Bayesian hierarchical analysis. Pages 198-117 in J. S. Clark and A. E. Gelfand, editors. Applications of computational statistics in the environmental sciences: hierarchical Bayes and MCMC methods. Oxford University Press, Oxford, UK.

Oksanen, J., R. Kindt, P. Legendre, B. O'Hara, G. L. Simpson, P. Solymos, M. H. H. Stevens, and H. Wagner. 2009. vegan: community ecology package. $\mathrm{R}$ package version $1.15-2$. $\langle$ http://cran.r-project.org/〉

Ostertag, R., F. N. Scatena, and W. L. Silver. 2003. Forest floor decomposition following hurricane litter inputs in several Puerto Rican forests. Ecosystems 6:261-273.

Ostertag, R., W. L. Silver, and A. E. Lugo. 2005. Factors affecting mortality and resistance to damage following hurricanes in a rehabilitated subtropical moist forest. Biotropica 37:16-24.

Paine, R. T., M. J. Tegner, and E. A. Johnson. 1998. Compounded perturbations yield ecological surprises. Ecosystems 1:535-545.

Pascarella, J. B., T. M. Aide, and J. K. Zimmerman. 2004. Short-term response of secondary forests to hurricane disturbance in Puerto Rico, USA. Forest Ecology and Management 199:379-393.

Pickett, S. T. A., and P. S. White. 1985. The ecology of natural disturbance and patch dynamics. Academic Press, Orlando, Florida, USA.

R Development Core Team. 2009. R: a language and environment for statistical computing. R Foundation for Statistical Computing, Vienna, Austria.

Rhemtulla, J. M., D. J. Mladenoff, and M. K. Clayton. 2009. Legacies of historical land use on regional forest composition and structure in Wisconsin, USA (mid-1800s-1930s-2000s). Ecological Applications 19:1061-1078.

Rivera, L. W., J. K. Zimmerman, and T. M. Aide. 2000. Forest recovery in abandoned agricultural lands in a karst region of the Dominican Republic. Plant Ecology 148:115-125. 
Scatena, F. N., and M. C. Larsen. 1991. Physical aspects of Hurricane Hugo in Puerto Rico. Biotropica 23:317-323.

Silver, W. L., L. M. Kueppers, A. E. Lugo, R. Ostertag, and V. Matzek. 2004. Carbon sequestration and plant community dynamics following reforestation of tropical pasture. Ecological Applications 14:1115-1127.

Silver, W. L., R. Ostertag, and A. E. Lugo. 2000. The potential for carbon sequestration through reforestation of abandoned tropical agricultural and pasture lands. Restoration Ecology 8:394-407.

Sousa, W. P. 1984. The role of disturbance in natural communities. Annual Review of Ecology and Systematics 15:353-391.

Sustache, J. A. 2004. Post-hurricane growth and recruitment of plant species used by birds in northern Puerto Rico. Thesis. University of Puerto Rico, Mayaguez, Puerto Rico.

Swaine, M. D., and T. C. Whitmore. 1988. On the definition of ecological species groups in tropical rain forest. Vegetatio 75: 81-86.

Thompson, J., N. Brokaw, J. K. Zimmerman, R. B. Waide, E. M. Everham III, D. J. Lodge, C. M. Taylor, D. GarciaMontiel, and M. Fluet. 2002. Land use history, environment, and tree composition in a tropical forest. Ecological Applications 12:1344-1363.

Thompson, J., N. Brokaw, J. K. Zimmerman, R. B. Waide, E. M. Everham III, and D. A. Schaefer. 2004. Luquillo Forest Dynamics Plot, Puerto Rico, United States. Pages 540-550 in E. Losos and E. G. Leigh, editors. Tropical forest diversity and dynamism: findings from a large-scale plot network. University of Chicago Press, Chicago, Illinois, USA.

Uriarte, M., C. D. Canham, J. Thompson, and J. K. Zimmerman. 2004a. A neighborhood analysis of tree growth and survival in a hurricane-driven tropical forest. Ecological Monographs 74:591-614.

Uriarte, M., C. D. Canham, J. Thompson, J. K. Zimmerman, and N. Brokaw. 2005. Seedling recruitment in a hurricanedriven tropical forest: light limitation, density-dependence and the spatial distribution of parent trees. Journal of Ecology 93:291-304.

Uriarte, M., C. D. Canham, J. Thompson, J. K. Zimmerman, L. Murphy, A. M. Sabat, N. Fetcher, and B. L. Haines. 2009. Understanding disturbance and human land use as determinants of tropical forest dynamics: results from a forest simulator. Ecological Monographs 79:423-443.
Uriarte, M., L. W. Rivera, J. K. Zimmerman, T. M. Aide, A. G. Power, and A. S. Flecker. 2004b. Effects of land use history on hurricane damage and recovery in a Neotropical forest. Plant Ecology 174:49-58.

Venables, W. N., and B. D. Ripley. 2002. Modern applied statistics with S. Springer-Verlag, New York, New York, USA.

Walker, L. R. 1991. Tree damage and recovery from Hurricane Hugo in Luquillo Experimental Forest, Puerto Rico. Biotropica 23:379-385.

Walker, L. R., D. J. Lodge, S. M. Guzman-Grajales, and N. Fetcher. 2003. Species-specific seedling responses to hurricane disturbance in a Puerto Rican rain forest. Biotropica 35: $472-485$.

Walsh, R. P. D. 1996. Climate. Pages 159-205 in P. W. Richards, editor. The tropical rainforest: an ecological study. Cambridge University Press, Cambridge, UK.

Weaver, P. L., and R. A. Birdsey. 1986. Tree succession and management opportunities in coffee shade stands. Turrialba $36: 47-58$

Webster, P. J., G. J. Holland, J. A. Curry, and H. R. Chang. 2005. Changes in tropical cyclone number, duration, and intensity in a warming environment. Science 309:1844-1846.

Whitmore, T. C., and D. F. R. P. Burslem. 1998. Major disturbances in tropical rainforests. Pages $549-565$ in D. M. Newbery, H. H. T. Prins, and N. D. Brown, editors. Dynamics of tropical communities. Blackwell Science, Oxford, UK

Wolda, H. 1981. Similarity indices, sample size and diversity. Oecologia 50:296-302.

Wright, S. J. 2005. Tropical forests in a changing environment. Trends in Ecology and Evolution 20:553-560.

Zens, M. S., and D. R. Peart. 2003. Dealing with death data: individual hazards, mortality and bias. Trends in Ecology and Evolution 18:366-373.

Zimmerman, J. K., E. M. Everham III, R. B. Waide, D. J Lodge, C. M. Taylor, and N. V. L. Brokaw. 1994. Responses of tree species to hurricane winds in subtropical wet forest in Puerto Rico: implications for tropical tree life-histories. Journal of Ecology 82:911-922.

Zimmerman, J. K. H., and A. P. Covich. 2007. Damage and recovery of riparian sierra palms after Hurricane Georges: influence of topography and biotic characteristics. Biotropica $39: 43-49$. 